(C) 2021, The Authors. Published by Elsevier Inc. and Fass Inc. on behalf of the American Dairy Science Association ${ }^{\circledR}$. This is an open access article under the CC BY-NC-ND license (http://creativecommons.org/licenses/by-nc-nd/4.0/).

\title{
Subclinical mastitis in dairy cows in major milk-producing areas of Sri Lanka: Prevalence, associated risk factors, and effects on reproduction
}

\author{
R. M. S. B. K. Ranasinghe, ${ }^{1 *}$ R. M. C. Deshapriya, ${ }^{2}$ D. I. Abeygunawardana, ${ }^{3}$ R. Rahularaj, ${ }^{4}$ \\ and C. M. B. Dematawewa ${ }^{2}$ \\ ${ }^{1}$ Department of Basic Veterinary Sciences, Faculty of Veterinary Medicine and Animal Science, University of Peradeniya, Peradeniya, 20400, \\ Sri Lanka \\ ${ }^{2}$ Department of Animal Science, Faculty of Agriculture, University of Peradeniya, Peradeniya, 20400, Sri Lanka \\ ${ }^{3}$ Department of Livestock and Avian Sciences, Faculty of Livestock, Fisheries and Nutrition, Wayamba University of Sri Lanka, Makandura, \\ Gonawila (NWP), 60170, Sri Lanka \\ ${ }^{4}$ Postgraduate Institute of Agriculture, University of Peradeniya, Peradeniya, 20400, Sri Lanka
}

\begin{abstract}
Compared with clinical mastitis, the subclinical form of mastitis (SCM) is more common and thought to cause more economic losses to the dairy industry. The current study aimed to investigate the prevalence, risk factors of SCM, and effects on reproduction of dairy cows in major milk-producing areas of Sri Lanka. A total of 1,357 cows of selected farms in 3 regions were examined in the study. California Mastitis Test was conducted for individual cows, and a score of 2 or more for any quarter without any clinical symptoms and abnormalities in milk was considered as positive for SCM. Samples from infected animals were collected and subjected to bacteriological analysis. A pretested questionnaire was used to collect data on individual cows and herds. Risk factors associated with SCM were analyzed using binary logistic regression in generalized linear mixed models. The effect of SCM on calving to conception interval and days from calving to artificial insemination were analyzed by survival analysis using Cox's proportional hazards regression and Kaplan-Meier survival function estimates, respectively. A Poisson regression model was run to determine the effect of SCM on number of artificial inseminations per conception. The prevalence of SCM was 57.5, 11.8, and $45.5 \%$ in the regions A, B, and $\mathrm{C}$, respectively. The most common pathogen was Staphylococcus aureus, with $87.1,56.5$, and $92.3 \%$ in the regions $\mathrm{A}, \mathrm{B}$, and $\mathrm{C}$, respectively. Logistic regression analysis showed that parity, farming system, milking area, region, and herd significantly affect the prevalence
\end{abstract}

Received January 27, 2021.

Accepted July 14, 2021.

*Corresponding author: bimalkarana@pdn.ac.lk or bimalka@vet .pdn.ac.lk of SCM. Subclinical mastitis during the pre-breeding period was associated with $14 \%$ increase in the chance of having a greater number of artificial inseminations per conception. Likewise, median days from calving to artificial insemination was longer in cows with SCM compared with normal cows (79 and $64 \mathrm{~d}$, respectively). Therefore, SCM affected the inseminated proportion of studied cows. However, SCM was not associated with the calving to conception interval. The results revealed that the cow factors and milk hygiene play a significant role in the prevalence of SCM.

Key words: dairy cow, reproductive parameter, risk factor, subclinical mastitis

\section{INTRODUCTION}

Mastitis causes pathological changes in the udder and chemical, physical, bacteriological, and organoleptic changes in milk (Sharma, 2007). It is widespread in dairy herds all over the world, accounting for huge economic losses, and the Sri Lankan dairy industry is no exception. Such losses have been due to reduced milk production and quality, milk discarding following treatment, increased treatment cost, increased labor, death, and premature culling (Losinger, 2005; Halasa et al., 2007; Hogeveen et al., 2011).

The effect of subclinical mastitis (SCM) on the dairy industry is aggravated by its asymptomatic nature making diagnosis difficult (Viguier et al., 2009). Further it is more widespread than the clinical form, lasts for a longer duration, and constitutes a reservoir of microorganisms that can affect healthy animals within the herd (Seegers et al., 2003). In Sri Lanka, 4,454 mastitis cases have been reported and the prevalence of clinical mastitis was $1.78 \%$ during the third quarter of the year 2015 (Department of Animal Production and Health, 2015a,b). Few studies conducted in selected areas of Sri Lanka have revealed that Staphylococcus aureus, Strep- 
tococcus spp., Klebsiella spp., and Escherichia coli are the most common pathogens causing mastitis. (Wickramasuriya, 1985; Sanotharan et al., 2016; Rahularaj et al., 2019). The diverse risk factors for the disease include cow, management, and environmental factors (Yamane et al., 2003). Further, recent reports indicated that reduced reproductive performance is due to both subclinical (Schrick et al., 2001; Lavon et al., 2011a,b; Hudson et al., 2012) and clinical mastitis (Santos et al., 2004; Nguyen et al., 2011; Hudson et al., 2012), which further increases the economic losses of mastitis.

Mastitis is a major production related disease of Sri Lankan dairy cattle and a significant barrier for reaching the national goal of self-sufficiency in dairy production (Gunawardana et al., 2014). Efficient disease surveillance mechanism for SCM is lacking in the country, and therefore, it is thought that the estimated figures are higher compared with the reported figures (Gunawardana et al., 2014). Lack of standard mastitis control and prevention practices across the country is also a contributing factor for the prevalence of SCM. Treatment failures are common due to either inappropriate use of antimicrobials or drug-resistant microorganisms. It is essential to determine the prevalence and potential risk factors for SCM to minimize the economic losses and to promote safer dairy production in Sri Lanka. Although a few studies have reported the prevalence and risk factors for mastitis and SCM in selected areas, in depth studies on the prevalence and associated risk factors of SCM in the major milk-producing areas are scarce (Samarakoon et al., 2014; Sanotharan et al., 2016; Rahularaj et al., 2019). Rahularaj et al. (2019) have found a positive correlation between SCM and calving interval in a major milk-producing area of Sri Lanka. However, the effect of SCM on other reproductive parameters such as calving to conception interval (CCI), number of AI per conception (NAIC), and days from calving to insemination (DCAI) have not been investigated in Sri Lankan dairy cows. Therefore, the current study was conducted with the aim of detecting the prevalence and risk factors of SCM and its effects on reproduction in dairy cattle in major milk-producing regions of Sri Lanka.

\section{MATERIALS AND METHODS}

\section{Study Locations and Animals}

A set of 1,357 lactating cows from 3 regions [region A: Kurunegala district of North Western Province (n $=200$ ); region B: Nuwara Eliya and Kandy districts of Central Province $(\mathrm{n}=805)$; region $C$ : Ampara district of Eastern Province $(\mathrm{n}=352)$ ] comprising the highest milk-producing regions of the country were used in the study (Figure 1). The study was conducted from April 2014 to July 2015. The herds $(\mathrm{n}=142)$ were randomly selected with the permission of Provincial Directors and National Livestock Development Board (NLDB), and all the selected farms agreed to participate in the study. In the present study, herds with $\leq 10,11$ to 50 , and $>50$ milking cows were classified as small-, medium-, and large-scale farms, respectively. If cows were kept in a shed for $24 \mathrm{~h}$ and supplied feed (zero grazing), those farms were classified as intensive system. Farms in which cows were tethered at about $0800 \mathrm{~h}$ after morning milking and brought back to the sheds around $1430 \mathrm{~h}$ were defined as the semi-intensive system (Bandara et al., 2011). Night feeding was practiced in both systems. The distribution of herds according to the management characteristics is given in Table 1 . In region $\mathrm{A}$, a total of 200 cows from 4 large-scale farms and 7 smallscale farms were examined. Cows were mainly crosses of Jersey and Sahiwal, housed in freestall barns, and managed primarily in a semi-intensive system. They were milked twice daily using machine milking, hand milking, or both, with a daily average milk yield of $6 \mathrm{~L}$. They were fed with natural pasture and concentrates. Region B included a total of 805 cows from 4 large-scale farms and 17 small-scale farms, and the majority of the cows were European pure breeds, managed intensively in freestall barns. They were milked twice daily using machine milking or hand milking with a daily average milk yield of 10 to $11 \mathrm{~L}$. In region C, 352 cows were examined from 110 small-scale farms with cows that were crosses of European breeds and Sahiwal. The cows were managed in small sheds under the semi-intensive management system. They were hand milked twice daily. For all cows, cut and feeding was practiced with the provision of concentrates, vitamins, and mineral mixtures in accordance with their level of production. Certain farms of the region $\mathrm{C}$ had a small separate pen used for milking and other purposes such as examination of cows. These sheds were classified as separate sheds and had a facility to tie the cows. If milking was done in the housing facility where the cows were kept, it was classified as milking in rearing pens. Some farmers used to bring the animals outside the shed and tether to a tree for milking; such a system was classified as an outdoor area. The cows were examined during their prebreeding season for SCM, and the subsequent reproductive performance was evaluated. Cows were examined for SCM from 14 DIM until around 63 DIM. Cows with a history of reproductive problems such as retained placenta, repeat breeding, or any other systemic disease at the time of examination were excluded from the study. 


\section{Estrus Detection, Al, and Pregnancy Diagnosis}

Cows were visually observed for behavioral signs of estrus during morning and afternoon milking by trained government field livestock officers and milkers consistently across herds. Standing to be mounted was considered the primary sign of being in estrus and cows were also observed for the secondary estrous signs such as mucus discharge from vulva and swelling, congestion, and relaxation of vulva. Artificial insemination was performed according to the a.m.-p.m. rule, generally $12 \mathrm{~h}$ after detecting estrus. In all herds AI was done based on estrus detection with no estrus synchro-

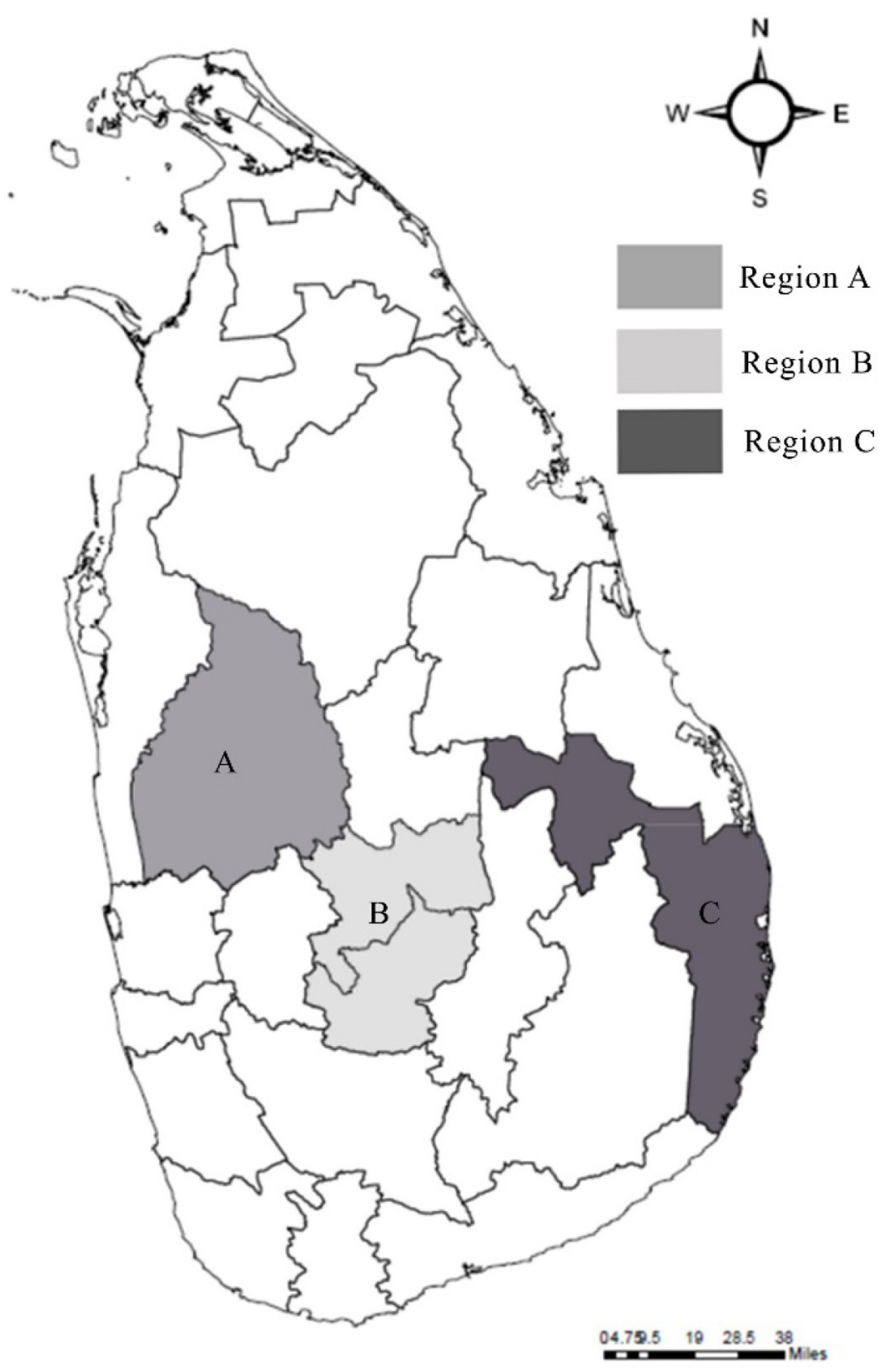

Figure 1. Map of regions included in the study, with total number of dairy farms (total number of milking cows) in 2015. Region A (Kurunegala district): 22,395 (28,239); Region B (Nuwara Eliya and Kandy districts): 19,604 (16,723); Region C (Ampara district): 8,702 $(17,368)$; Department of Census and Statistics, 2020; Department of Animal Production and Health, 2015a. nization or strict adherence to a voluntary waiting period. Inseminations were performed by an experienced technician attached to the Government Veterinary Surgeon's Office or NLDB, using frozen-thawed semen from the Central Artificial Insemination Station (Kundasale, Kandy, Sri Lanka). Pregnancy was diagnosed by transrectal palpation by the veterinary surgeons of the Government Veterinary Surgeon's Office or NLDB, 35 to $40 \mathrm{~d}$ after insemination.

\section{Identification of Animals with SCM: Sample and Data Collection}

The use of cows and experimental procedures complied with the guidelines of the Ethics Review Committee, Faculty of Livestock, Fisheries and Nutrition, Wayamba University of Sri Lanka. In total, 142 herds were visited during morning milking. Cows with clinical mastitis were initially identified and excluded from the study, and the California Mastitis Test (CMT; Quinn et al., 1999) was used to detect cows with SCM. The CMT results were scored as 0 (negative: consistency normal, no gel formation), 1 (trace: light gel formation, purplish gray color), 2 (positive: light persistent gel, purple gray), 3 (positive: immediate thickening, viscous cluster at the bottom of the well), and 4 (positive: thick gel consistency of egg white, dark purple) (Gunawardana et al., 2014; Kayesh et al., 2014). All CMT scores of 0 and 1 were considered negative, whereas cows having a score of 2 or more for at least one quarter with a visibly normal udder and normal milk were categorized as having SCM. To minimize the inconsistencies of CMT, 2 of the experienced authors of this paper performed all CMT tests. Before sample collection, teats were washed with clean water, wiped and dried with disposable paper towels, and disinfected with $70 \%$ ethyl alcohol, and the first few streams of milk were discarded. Before milking, composite foremilk samples $(10 \mathrm{~mL})$ from CMT positive quarters were aseptically collected into sterilized glass bottles and transported in cool condition (ice box) to the laboratory for bacteriological examination.

Record keeping was minimal on small-scale farms; therefore, reproductive data were not available. In large-scale farms data were recorded by the staff of the farm on individual cow cards, which were used to collect individual cow data and data of reproductive parameters. Herd- and management-related information was collected by interviewing the farm managers through a pretested, structured questionnaire. Milk yield data were summarized as average daily milk yield for the month of the SCM diagnosis was performed. Follow-up visits were conducted to complete the recording of data and to confirm the reproductive status of cows. 
Table 1. Distribution of herds among region, farming system, milking method, and milking area

\begin{tabular}{|c|c|c|c|c|c|c|c|c|}
\hline \multirow[b]{3}{*}{ Milking method } & \multirow[b]{3}{*}{ Milking area } & \multicolumn{6}{|c|}{ Region $^{1}$ and farming system ${ }^{2}$} & \multirow[b]{3}{*}{ Total } \\
\hline & & \multicolumn{2}{|c|}{$\mathrm{A}$} & \multicolumn{2}{|c|}{$\mathrm{B}$} & \multicolumn{2}{|c|}{$\mathrm{C}$} & \\
\hline & & I & SI & I & SI & I & SI & \\
\hline \multirow[t]{3}{*}{ Hand milking } & Separate shed & 0 & 3 & $0 / 1^{3}$ & 0 & 3 & 11 & 18 \\
\hline & Rearing shed & 0 & 2 & 15 & 0 & 6 & 50 & 73 \\
\hline & Outdoor area & 0 & 3 & 3 & 0 & 0 & 40 & 46 \\
\hline Machine milking & Outdoor area & 0 & 0 & 0 & 0 & 0 & 0 & 0 \\
\hline \multirow[t]{3}{*}{ Both hand and machine milking } & Separate shed & 0 & 0 & 0 & 0 & 0 & 0 & 0 \\
\hline & Rearing shed & 1 & 0 & 0 & 0 & 0 & 0 & 1 \\
\hline & Outdoor area & 0 & 0 & 0 & 0 & 0 & 0 & 0 \\
\hline Total & & 3 & 8 & 22 & 0 & 9 & 101 & $143^{4}$ \\
\hline
\end{tabular}

${ }^{1}$ Region: $\mathrm{A}=$ Kurunegala district; $\mathrm{B}=$ Nuwara Eliya and Kandy districts; $\mathrm{C}=$ Ampara district.

${ }^{2}$ Farming system: $\mathrm{I}=$ intensive system; $\mathrm{SI}=$ semi-intensive system.

${ }^{3}$ In large-scale farm 07, 8 cows were machine milked in a separate shed and 37 cows were hand milked in the rearing shed.

${ }^{4}$ Large-scale farm 07 has been counted twice.

\section{Bacteriological Examination of Milk Samples}

Bacteriological examination of the samples collected from regions $\mathrm{A}, \mathrm{B}$, and $\mathrm{C}$ were carried out at the Pannala Veterinary Investigation Centre, Ampara Veterinary Investigation Centre, and laboratory of the Department of Livestock and Avian Sciences, respectively. The study focused on isolating and identifying 3 main genera of mastitis-causing pathogens reported in Sri Lanka: Staphylococcus spp., Streptococcus spp., and E. coli. Depending on the feasibility of analysis (e.g., maximum number of samples that can be analyzed within $6 \mathrm{~h}$ of collection), a subset of collected samples was cultured for bacteriological examination. The presence of Staph. aureus was confirmed by a separate study using PCR (Ravinath et al., 2014).

The samples were refrigerated and analyzed within $6 \mathrm{~h}$ of collection. Refrigerated samples were brought to room temperature, stirred, and inoculated onto blood agar enriched with $7 \%$ of sheep blood. Then, inoculated plates were aerobically incubated at $37^{\circ} \mathrm{C}$ for 24 to 48 $\mathrm{h}$ to detect growth of pathogens and hemolytic characters of the colonies. Depending on the results of Gram staining, either a catalase test was done to differentiate Staphylococcus spp. and Streptococcus spp. or colonies were subcultured in MacConkey agar to identify E. coli. Following incubation of inoculated plates at $37^{\circ} \mathrm{C}$ for 24 to $48 \mathrm{~h}$, morphological characters and the color of the colonies were examined. The indole test was also done to differentiate E. coli from Klebsiella spp. Results of Gram staining, colony morphology, and biochemical tests were used to arrive at a final bacteriological diagnosis.

\section{Data Management and Statistical Analyses}

The proportion of animals with SCM in each region was given as a percentage of the total number of animals examined in the respective region. Prevalence of SCM and different organisms identified in each region were given as percentages. Variables associated with SCM were initially checked in the univariate analysis. The best-fitting model for variables associated with SCM was built using binary logistic regression in generalized linear mixed model using all variables that were associated with an outcome of interest in the univariate analysis. Breed (Holstein, Jersey, or crosses that included any cross between Holstein, Jersey, Sahiwal, and local cattle), parity (primiparous or multiparous), farming system (semi-intensive or intensive), milking area (separate shed, rearing shed, or outdoor area), milking method (hand milking, machine milking, or both), region (A, B, or C), and milk yield $<10,10-20$, or $>20 \mathrm{~L}$ ) were included in the model as fixed effects. Herd (1-142) was included as a random effect in the model.

Cox's proportional hazards regression of multivariable survival analysis was used to analyze the effect of SCM on CCI. In addition to the main effect (SCM), breed, parity, farming system, and region (regions A and B) were fitted as covariates. Models were built by manual backward stepwise elimination, removing the covariate with the largest probability value at each step, until all covariates were significant at $P=0.05$. If one level of a categorical variable was significant, all levels were retained. Reproductive data were available only in some farms of regions A and B. About 815 
Table 2. Prevalence of subclinical mastitis (SCM) in dairy cows in major milk-producing areas of Sri Lanka

\begin{tabular}{llcr}
\hline Region $^{1}$ & Farm (no. of farms) & $\begin{array}{c}\text { No. of cows } \\
\text { examined }\end{array}$ & $\begin{array}{c}\text { No. of cows positive } \\
\text { for SCM (\%) }\end{array}$ \\
\hline A & Large-scale farm 01 & 48 & $30(62.5)$ \\
& Large-scale farm 02 & 53 & $24(45.3)$ \\
& Large-scale farm 03 & 17 & $10(58.8)$ \\
& Large-scale farm 04 & 57 & $34(59.6)$ \\
B & Small-scale farms (7) & 25 & $17(68.0)$ \\
& Total for region A & 200 & $115(57.5)$ \\
& Large-scale farm 05 & 434 & $26(6.0)$ \\
& Large-scale farm 06 & 273 & $28(10.3)$ \\
& Large-scale farm 07 & 45 & $30(66.7)$ \\
C & Large-scale farm 08 & 16 & $1(6.3)$ \\
& Small-scale farms (17) & 37 & $10(27.0)$ \\
Total & Total for region B & 805 & $95(11.8)$ \\
\hline
\end{tabular}

${ }^{1}$ Region: $\mathrm{A}=$ Kurunegala district; $\mathrm{B}=$ Nuwara Eliya and Kandy districts; $\mathrm{C}=$ Ampara district.

cows had NAIC records. As NAIC was a count variable with many levels, a Poisson regression model was used to determine the effect of SCM on NAIC. Breed, parity, farming system, and region were also included in the model as independent variables. Records of CCI and DCAI of 675 cows were used for survival analysis. Kaplan-Meier survival function estimates were used to calculate crude associations between diseased and healthy animals with median DCAI, as well as to generate graphs of cumulative proportion inseminated over time. All analyses were performed with SPSS version 23.0 (SPSS Inc.), with cow as the experiment unit.

\section{RESULTS}

\section{Prevalence and Major Pathogens of SCM}

A total of $370(27.3 \%)$ samples were identified as positive for SCM (CMT score $\geq 2$ ), out of which 303 SCM-positive milk samples were examined by bacteriological culture to identify the pathogens causing SCM; 297 samples had colony-forming units. The prevalence of $\mathrm{SCM}$ among the regions $\mathrm{A}, \mathrm{B}$, and $\mathrm{C}$ were 57.5 ,
11.8 , and $45.5 \%$, respectively (Table 2). Staphylococcus aureus was the most common pathogen present in the CMT positive milk samples from all 3 regions (87.1, 56.5 , and $92.3 \%$, respectively). The second highest was E. coli in regions A and C (12.9 and $6.3 \%$, respectively), and Streptococcus spp. in region B (10.8\%; Table 3). Approximately $23.0 \%$ of cultures of region B were positive for more than one organism. Klebsiella spp. was not present in any of the samples.

\section{Risk Factors for SCM}

The risk factors associated with SCM in major milkproducing areas of Sri Lanka are shown in Table 4. Results indicated that parity $(P<0.0001)$, farming system $(P=0.017)$, milking area $(P=0.015, P=$ $0.003)$, and region $(P=0.036)$ significantly contributed to the risk of SCM among the cows studied. In multiparous cows, the odds of having SCM were 2.51 times greater than the odds for primiparous cows. Intensive system was associated with a greater risk of having SCM compared with cows reared under semi-intensive system (odds ratio $=5.03$ ). For the cows that were

Table 3. Percentage of different pathogens identified from dairy cows with subclinical mastitis (SCM) in major milk-producing areas of Sri Lanka

\begin{tabular}{lcccc}
\hline & & & \multicolumn{2}{c}{ Pathogen $(\%)$} \\
\cline { 3 - 4 } Region $^{1}$ & $\begin{array}{c}\text { No. of culture } \\
\text { positive samples }\end{array}$ & $\begin{array}{c}\text { Staphylococcus } \\
\text { aureus }\end{array}$ & $\begin{array}{c}\text { Escherichia } \\
\text { coli }\end{array}$ & $\begin{array}{c}\text { Streptococcus } \\
\text { spp. }\end{array}$ \\
\hline $\mathrm{A}$ & 62 & $54(87.1)$ & $8(12.9)$ & - \\
$\mathrm{B}^{2}$ & 92 & $52(56.5)$ & $9(9.8)$ & $10(10.8)$ \\
$\mathrm{C}$ & 143 & $132(92.3)$ & $9(6.3)$ & $2(1.4)$ \\
Total & 297 & $238(80.1)$ & $26(8.8)$ & $12(4.0)$ \\
\hline
\end{tabular}

${ }^{1}$ Region: $\mathrm{A}=$ Kurunegala district; $\mathrm{B}=$ Nuwara Eliya and Kandy districts; $\mathrm{C}=$ Ampara district.

${ }^{2} 21$ samples were positive for more than 1 organism and not shown here. 
Table 4. Adjusted odds ratios (OR) and 95\% CI of the variables included in the binary logistic regression model of generalized linear mixed model for risk factors for subclinical mastitis (SCM) in dairy cows in major milk-producing areas of Sri Lanka

\begin{tabular}{|c|c|c|c|c|c|c|}
\hline Variable & Level & $\mathrm{N}^{1}$ & $\%$ & OR & $95 \%$ CI & $P$-value \\
\hline Breed $^{2}$ & Jersey & 27 & 9.0 & 0.79 & $0.21-3.00$ & 0.730 \\
\hline Parity & Multiparous & 276 & 26.7 & 2.51 & $1.61-3.93$ & $<0.0001$ \\
\hline \multirow[t]{2}{*}{ Farming system } & Semi-intensive & 234 & 47.4 & & & \\
\hline & Intensive & 136 & 15.8 & 5.03 & $1.34-18.87$ & 0.017 \\
\hline Milking area & Outdoor area & 74 & 52.9 & 5.87 & $1.86-18.48$ & 0.003 \\
\hline \multirow{3}{*}{ Milking method } & Hand milking & 256 & 46.4 & & & \\
\hline & Machine milking & 73 & 10.1 & 0.64 & $0.13-3.27$ & 0.599 \\
\hline & Both & 41 & 63.1 & 2.70 & $0.20-36.69$ & 0.456 \\
\hline \multirow[t]{3}{*}{ Region $^{3}$} & A & 115 & 57.5 & & & \\
\hline & B & 95 & 11.8 & 0.10 & $0.01-0.86$ & 0.036 \\
\hline & $\mathrm{C}$ & 160 & 45.5 & 0.71 & $0.19-2.71$ & 0.620 \\
\hline
\end{tabular}

${ }^{1}$ Number of SCM-positive cows in each category.

${ }^{2}$ Number of missing data: breed $=38$; average milk yield $=33$ (taken into consideration during data analysis).

${ }^{3}$ Region: $\mathrm{A}=$ Kurunegala district; $\mathrm{B}=$ Nuwara Eliya and Kandy districts; $\mathrm{C}=$ Ampara district.

milked in the rearing shed and outdoor areas, the odds of being diagnosed with SCM were 3.56 and 5.87 times greater, respectively, than those milked in a separate shed. There was no significant effect of breed, milking method, and milk yield on the prevalence of SCM. The herd was also a significant risk factor for the occurrence of SCM $(P<0.0001)$. However, univariate analysis showed that the average daily milk yield (mean \pm SEM) of cows having SCM was significantly lower than that of healthy cows $(9.25 \pm 0.50$ vs. $14.90 \pm 0.26$ $\mathrm{L} / \mathrm{d}, P<0.0001)$.

\section{Effect of SCM on Reproductive Performance}

The effect of SCM on CCI is shown in Table 5 . Calving to conception interval (mean \pm SEM) for the SCM-positive and healthy cows were $202.64 \pm 13.29$ and $195.96 \pm 6.60$, respectively, and not significantly different between the 2 groups $(P=0.29)$. In the final model, breed [hazard ratio $(\mathbf{H R})=2.36$ and 2.09, $P<$ $0.0001]$, parity $(\mathrm{HR}=1.77, P<0.0001)$, farming system $(\mathrm{HR}=0.41, P=0.028)$, and region $(\mathrm{HR}=4.64, P=$ $0.001)$ were significantly associated with CCI. The likelihood ratio $\chi^{2}$ of the Poisson regression indicated that the model was significant $(P<0.0001)$ and SCM was a significant predictor of NAIC. Subclinical mastitis during the prebreeding period was associated with a $14 \%$ increase in NAIC (Table 6) in the subsequent service period. The incidence rate ratio (IRR) indicates that the SCM increases the incidence rate (for NAIC) by a factor of $0.857(\operatorname{IRR}=0.857, P<0.0001)$. Other than
SCM, parity $(\mathrm{IRR}=1.096, P=0.053)$ and region $(\mathrm{IRR}$ $=1.398, P<0.001)$ were also significantly associated with NAIC in the final model (Table 6). The DCAI in cows that were positive for SCM was hindered by $15 \mathrm{~d}$ compared with those that were healthy (median d 79 and $64, P=0.02$ : Figure 2).

\section{DISCUSSION}

Subclinical mastitis, being an economically important disease of dairy industry, needs to be investigated in depth in Sri Lanka. Although the prevalence and risk factors for SCM have been reported in some parts of the country, its effects on fertility remain questionable (Gunawardana et al., 2014; Sanotharan et al., 2016).

The overall incidence of SCM in the current study was $27.3 \%$, which is low compared with some of the previous studies conducted in similar management systems of Sri Lanka (Sanotharan et al., 2016, 43.0\%; Rahularaj et al., 2019, 49.0\%). However, comparable prevalence levels were found in similarly hot tropical regions of Mexico (Olivares-Pérez et al., 2015) and in crossbred dairy cow herds managed under semi-intensive system in Bangladesh (Islam et al., 2011). Other studies conducted in smallholder dairy farms with both grazing and zero grazing in Kampala, Uganda (Abrahmsén et al., 2014), and under intensive management system in southern Brazil (Cardozo et al., 2015) and Poland (Sztachanska et al., 2016) have reported higher prevalence rates of SCM compared with the present study. Abrahmsén et al. (2014) reported an exceptionally 
Table 5. Final Cox's proportional hazard regression model for the effect of subclinical mastitis (SCM) on calving to conception interval in dairy cows in major milk-producing areas of Sri Lanka

\begin{tabular}{llccc}
\hline Variable & Level & $\mathrm{HR}^{1}$ & $95 \% \mathrm{CI}$ & $P$-value \\
\hline Subclinical mastitis & Healthy & & \\
SCM positive & 1.05 & $0.84-1.31$ & 0.663 \\
Breed & Holstein & 2.36 & $1.89-2.96$ & $<0.0001$ \\
& Jersey & 2.09 & $1.63-2.68$ & $<0.0001$ \\
Crosses & & & $<0.0001$ \\
Parity & $\begin{array}{l}\text { Primiparous } \\
\text { Multiparous }\end{array}$ & 1.77 & $1.33-2.35$ & 0.028 \\
Farming system & Semi-intensive & 0.41 & $0.18-0191$ & $<0.0001$ \\
Region $^{2}$ & Intensive & & & \\
& A & 4.64 & $2.18-988$ &
\end{tabular}

${ }^{2}$ Region: $\mathrm{A}=$ Kurunegala district; $\mathrm{B}=$ Nuwara Eliya and Kandy districts.

high prevalence of SCM $(86.2 \%)$ in Uganda due to the risk factors such as zero grazing, poor udder hygienic practices, higher parity, and late stages of lactation. Katsande et al. (2013) reported a comparatively low incidence of SCM (16.3\%) in smallholder dairy farms in Zimbabwe; however, they have defined SCM as having an SCC of at least $300 \times 10^{3}$ cells $/ \mathrm{mL}$.

Staphylococcus aureus was the most common pathogen identified from CMT positive milk samples from all regions $(80.1 \%)$, which agrees with studies conducted under similar management systems in southern Ethiopia (Lidet et al., 2013; Abebe et al., 2016) and Bangladesh (Kayesh et al., 2014). Being a contagious pathogen, high prevalence of Staph. aureus in this study could be associated with poor milking hygiene, absence of dry cow therapy, and the invariable hand milking practices among the dairy herds. Although the hygienic practices during milking were not investigated in the present study, previous studies conducted in one of the above areas indicated that postmilking hygienic practices are not practiced, thus establishing the organism in dairy herds (Abeygunawardana et al., 2017; Ranasinghe et al., 2017). Further, the organism penetrates deeply into glandular epithelium and therefore, is difficult to eradicate with conventional antibiotic treatments during lactation (Tyler et al., 1993). The immune response of the cow is not successful in eliminating established infections with this pathogen. Thus, to combat this infection effectively, it is necessary to improve milking hygiene and apply control measures (Rainard et al., 2018). The prevalence of other pathogens, E. coli $(8.8 \%)$ and Streptococcus spp. (4.0\%) in the current study are in agreement with the results of Sanotharan et al. (2016) and Rahularaj et al. (2019).

This study revealed that parity, farming system, milking area, region, and herd were significantly associated with the prevalence of SCM. In the present study, compared with primiparous cows, multiparous cows were 2.51 times more likely to have SCM. Similarly, the higher prevalence of SCM in multiparous cows compared with primiparous cows has been reported in many studies under similar management systems (Sharma et al., 2018; Wang et al., 2019) and also in intensively managed herds (Hiitiö et al., 2017; Taponen

Table 6. Final Poisson regression model for the effect of subclinical mastitis (SCM) on number of AI per conception in dairy cows in major milk-producing areas of Sri Lanka

\begin{tabular}{llllc}
\hline Variable & Level & $\mathrm{IRR}^{1}$ & $95 \% \mathrm{CI}$ & $P$-value \\
\hline Subclinical mastitis & Healthy & 0.857 & $0.79-0.93$ & $<0.0001$ \\
& SCM positive & 1 & & \\
Breed & Holstein & 0.946 & $0.86-1.04$ & 0.255 \\
& Jersey & 0.925 & $0.84-1.02$ & 0.121 \\
\multirow{2}{*}{ Parity } & Crosses & 1 & & \\
& Primiparous & 1.096 & $1.00-1.20$ & 0.053 \\
Farming system & Multiparous & 1 & & 0.546 \\
Region $^{2}$ & Semi-intensive & 0.944 & $0.78-1.14$ & $<0.0001$ \\
& Intensive & 1 & $1.16-1.69$ & \\
\hline
\end{tabular}

${ }^{1} \mathrm{IRR}=$ incidence rate ratio.

${ }^{2}$ Region: $\mathrm{A}=$ Kurunegala district; $\mathrm{B}=$ Nuwara Eliya and Kandy districts. 
et al., 2017). Mechanisms underlying the phenomenon that the prevalence of SCM increases with age and parity are not well defined, but could be related to many factors associated with defense mechanism and teat and udder confirmation. The impairment of leukocyte function and less effective defense mechanism with increasing age of the cow are associated with high prevalence of SCM in older cows (Erskine, 2001; Rainard and Riollet, 2006). Increased potency of teats and increased previous exposure (Sisay et al., 2012), callosity of the teat end with increasing parity (Neijenhuis et al., 2001), and breakdown of the streak canal barriers and udder tissue with aging (Abrahmsén et al., 2014) are associated with higher susceptibility of older cows to SCM. Taponen et al. (2017) showed that the effect of parity on IMI varies according to the milking system and hence suggested to adapt different management practices for older cows.

A high incidence of SCM when cows were managed under an intensive system was observed in the current study. A previous study conducted in a different region of Sri Lanka with geographical and climatic conditions similar to region $\mathrm{C}$ of the current study also reported that cows reared under intensive management systems were 10.3 times more at risk of having SCM compared with cows managed under extensive systems (Sanotharan et al., 2016). In contrast, Begum et al. (2015) reported a

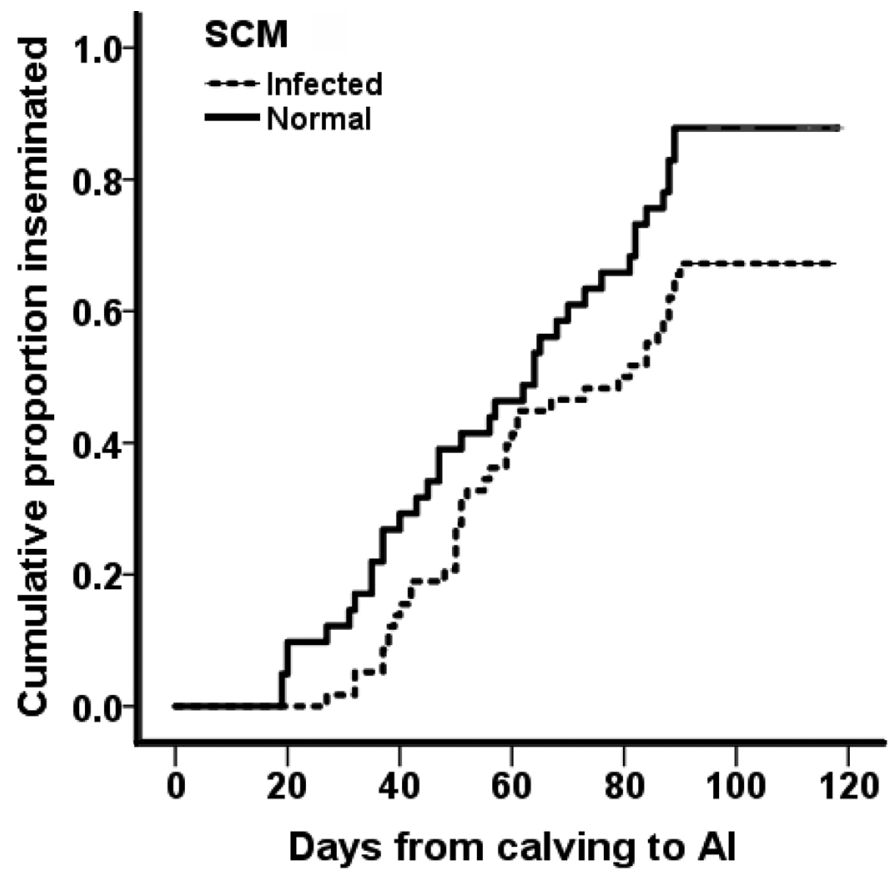

Figure 2. Kaplan-Meier survival function curves for the cumulative proportion inseminated against days from calving to AI for cows that infected with subclinical mastitis (SCM) and healthy cows (normal); log rank statistics, $P=0.015$. higher prevalence of SCM among semi-intensively managed cows $(27.6 \%)$ compared with those under intensive management systems (10.5\%). The above study was conducted under tropical climates in Bangladesh where cows under semi-intensive management conditions were reared in uncleaned and muddy common barns with bedding materials. Biffa et al. (2005) also reported that cows managed under semi-intensive system in Ethiopia were more affected $(43.8 \%)$ than those reared under extensive $(25.8 \%)$ and intensive $(28.9 \%)$ systems. This study included 2 regions of warm and dry climates where the semi-intensive system consisted of Holstein cows and their crosses managed in uncleaned common barns. The high incidence of SCM was suggested to be due to high susceptibility of Holsteins under poor hygienic conditions that favor the proliferation and transmission of pathogens, especially in rainy seasons. In the current study under semi-intensive management, mainly Jersey or Jersey crosses were maintained on concrete floors, thus leaving lesser chance for the occurrence of SCM. The difference in the prevalence of SCM in various management systems could be related to factors such as variation in environmental conditions, milk hygienic practices, and milking conditions that favor the proliferation and transmission of pathogens.

This study revealed that a cow milked in the rearing shed or outdoor areas had a 3.56 or a 5.87 times greater risk, respectively, of having SCM compared with a cow milked in a separate shed. Milking area was not included as a risk factor in almost all similar studies reported in other countries, perhaps because it is common to have a milking parlor in most of the herds. But the situation is not the same in most of the dairy farms in Sri Lanka. The farms that had separate sheds for milking were usually kept clean. Therefore, it is possible that separate sheds provide more hygienic environment for milking compared with the rearing sheds and outdoor areas. Most of the farmers who used outdoor areas for milking used to bring the cows outside the rearing pens and tether to a tree before milking. Those farms had minimal facilities, such as poor, temporary housing facilities. It was observed that those farmers were not concerned about hygienic aspects of milking. Therefore, when milking in outdoor areas and rearing sheds, cows are exposed to more pathogens than in an environment specifically made clean for milking.

It has been reported that high-yielding dairy cows, such as Holsteins, are more susceptible to SCM (Santman-Berends et al., 2016). However, breed was not a significant risk factor in the current study. The method of milking was also not significantly associated with the prevalence of SCM. Similarly, in the study of Wang et al. (2019), no significant association was detected between incidence of SCM and milking method. 
Although a positive association between mastitis and milk yield has been suggested in many studies, in the current study, milk yield group (low, medium, high) was not significantly associated with the occurrence of SCM. Similar results have been reported under intensive (Birhanu et al., 2017; Hiitiö et al., 2017) and semiintensive (Wang et al., 2019) management systems. In contrast, Sanotharan et al. (2016), Biswas and Sarker (2017), and Taponen et al. (2006) reported higher prevalence of SCM in cows with high milk production. However, univariate analysis showed that cows with SCM have a significantly lower average daily milk yield compared with healthy cows. It may be interesting to set a cut-off point for high milk yield for different management conditions and then to study the association between milk yield and SCM.

Herd was a risk factor for SCM in the present study. Such variations among herds were an ultimate result of combined effects of factors such as breed and milking method in addition to the other differences among herds such as hygienic milking practices, health management, and other environmental and management conditions.

Decreased reproductive performance due to SCM has been recorded in many regions of the world (Klaas et al., 2004; Pinedo et al., 2009; Lavon et al., 2011a). The studies that have investigated the effects of SCM on reproductive performance of dairy cows are rare in Sri Lanka (Rahularaj et al., 2019). Cows with SCM showed an increased NAIC compared with healthy cows. These results agree with the work of Schrick et al. (2001) in which cows with SCM in an intensively managed herd showed increased services per conception before the first service, compared with control (0.5 inseminations more). It has been also reported that SCM significantly increased the number of services per conception in a pasture-based managed system (Gómez-Cifuentes et al., 2014). In the study of Villa-Arcila et al. (2017), cows having SCM had on average 1.83 more services per conception than healthy cows in a rotational grazing system. In contrast, Mohapatra and Ashutosh, (2017) reported that number of services per conception did not differ significantly between the SCM and control groups in a population of crossbred cows. In the present study, DCAI in cows with SCM was 15 d longer compared with those that were healthy. Above results agree with the study of Schrick et al. (2001), in which days to first insemination was delayed by $8 \mathrm{~d}$ in infected cows before first AI compared with animals that were uninfected or exhibited mastitis after pregnancy was confirmed. Siatka et al. (2019) and Pinedo et al. (2009) have reported similar outcomes. In contrast, Villa-Arcila et al. (2017) and Mohapatra and Ashutosh (2017) stated that interval from calving to first service did not differ significantly between the cows with SCM and without
SCM. In the current study, CCI was not significantly different between SCM-positive and healthy cows. In contrast, in the study of Villa-Arcila et al. (2017), CCI was $24 \mathrm{~d}$ longer in the SCM-positive cows compared with healthy cows. Similarly, CCI was $48.7 \mathrm{~d}$ longer in Chilean dairy cattle with high SCC (Pinedo et al., 2009) and 22.3 d longer in Jersey cows (Schrick et al., 2001) compared with control cows.

The relationship between mastitis and fertility in dairy cows is multifaceted and multifactorial. Lavon et al. (2010) observed about $30 \%$ of the cows affected with SCM has delayed ovulation. In an experiment that corrected the timing of ovulation by a hormonal approach (Lavon et al., 2016), a longer estrus-to-ovulation interval has been recorded in cows affected with SCM $(56 \mathrm{~h})$ compared with uninfected cows $(28 \mathrm{~h})$. Peake et al. (2011) suggested that persistent SCM prolonged the interval from calving to first luteal phase. Delayed ovulation is associated with low circulating estradiol concentrations and low and delayed pre-ovulatory LH surges (Lavon et al., 2010). Cows with SCM exhibited low expression of major steroidogenic enzymes thus low steroid concentrations in the follicular fluid of pre-ovulatory follicles (Lavon et al., 2011b). Further, Furman et al. (2014) showed that the growth of early stage follicles is attenuated due to the exposure of toxins of gram-positive bacteria. A low follicular estradiol concentration was also noted more than 2 wk after gram-negative or gram-positive toxin exposure. Endotoxins interrupt the pre-ovulatory estradiol rise delaying the LH surge and subsequent ovulation (Suzuki et al., 2001). All above evidence suggest SCM disrupts the growth and function of developing follicles, and the induced damage is then carried over to pre-ovulatory follicles causing delayed ovulation. Delayed ovulation could interfere with the process of fertilization, subsequently leading to poor conception risk (number of pregnancies per number of inseminations; Lavon et al., 2016). Additionally, lipopolysaccharides of endotoxins of bacteria, $\mathrm{PGF}_{2 \alpha}$, and nitric oxide produced during inflammation can adversely affect oocyte maturation and embryonic development in cattle (Soto et al., 2003). Further, they can disrupt normal hormone levels and negatively affect corpus luteum development (Hansen et al., 2004; Schams and Berisha, 2004). Mastitis may also interfere with corpus luteum regression, progesterone secretion, and endometrial functions (Gilbert et al., 1990; Mann and Lamming, 2001; Spencer et al., 2004). Furthermore, low magnitude of LH surge has been shown to be associated with impaired luteinization of the corpus luteum and low circulating progesterone after ovulation and insemination, which may be associated with low embryo survival and increase in services per conception (Zelinski-Wooten et al., 1997; Bloch et al., 2006). The 
exact mechanisms by which mastitis is associated with suppression of fertility have yet to be resolved.

Loeffler et al. (1999) emphasized the significance of time of SCM occurrence for its effect on reproductive performance. According to Fuenzalida et al. (2015), SCM during breeding period had the greatest effects on pregnancy rates. The exact time of disease occurrence was not taken into consideration in the present study though cows in prebreeding period were included and subsequent reproductive parameters were analyzed. Studying the effect of SCM that occurs during defined time periods on reproduction may give more comprehensive results on the association of these 2 parameters.

\section{CONCLUSIONS}

The overall prevalence of SCM in major milkproducing areas of Sri Lanka was 27.3\%, and Staph. aureus was the most common pathogen identified from CMT-positive milk samples from all 3 major milk-producing regions. Subclinical mastitis was more prevalent in higher parity cows. Intensive farming system and outdoor milking also increased the risks for SCM in the study population. Occurrence of SCM significantly affected the reproductive performance by increasing the number of services per conception and calving to insemination interval.

\section{ACKNOWLEDGMENTS}

Financial assistance given by the Wayamba University Grant SRHDC/RP/04/14-04 is acknowledged. The authors thank the farm managers, staff, and farmers for their valuable help and cooperation in performing the study. The authors acknowledge the university research council, University of Peradeniya, and the National Research Council of Sri Lanka (Grant No. NRC-15-087), for paying the publication cost associated with the manuscript. The authors have not stated any conflicts of interest.

\section{REFERENCES}

Abebe, R., H. Hatiya, M. Abera, B. Megersa, and K. Asmare. 2016. Bovine mastitis: Prevalence, risk factors and isolation of Staphylococcus aureus in dairy herds at Hawassa milk shed, South Ethiopia. BMC Vet. Res. 12:270-281. https://doi.org/10.1186/s12917 -016-0905-3.

Abeygunawardana, D. I., R. M. S. B. K. Ranasinghe, and R. M. C. Deshapriya. 2017. Hygienic practices and quality of raw milk produced in a small scale dairy farming area in Sri Lanka. Int. J. Sci. Res. Publ. 7:72-77.

Abrahmsén, M., Y. Persson, B. M. Kanyima, and R. Båge. 2014. Prevalence of subclinical mastitis in dairy farms in urban and peri-urban areas of Kampala, Uganda. Trop. Anim. Health Prod. 46:99-105. https://doi.org/10.1007/s11250-013-0455-7.
Bandara, D. M. D. S., S. Premaratne, and C. M. B. Dematawewa. 2011. Production and economic characteristics of intensive and semi intensive dairy cattle management systems in vegetable based farming system in Welimada, Sri Lanka. Trop. Agric. Res. 22:314323. https://doi.org/10.4038/tar.v22i3.3704.

Begum, M. I. A., M. S. Hossain, M. Ershaduzzaman, M. N. Islam, and M. S. Rana. 2015. Study on prevalence and risk factors of Subclinical Mastitis in lactating dairy cows in Rajshahi and Rangpur Division of Bangladesh. Wayamba J. Anim. Sci. 7:1129-1137.

Biffa, D., E. Debela, and F. Beyene. 2005. Prevalence and risk factors of mastitis in lactating dry cows in southern Ethiopia. Int. J. Appl. Res. Vet. Med. 3:189-198.

Birhanu, M., S. Leta, G. Mamo, and S. Tesfaye. 2017. Prevalence of bovine subclinical mastitis and isolation of its major causes in Bishoftu Town, Ethiopia. BMC Res. Notes 10:767. https://doi .org/10.1186/s13104-017-3100-0.

Biswas, D., and T. Sarker. 2017. Prevalence of sub-clinical mastitis at Banaripara Upazilla, Barisal. Bangladesh J. Vet. Med. 15:21-26. https://doi.org/10.3329/bjvm.v15i1.34050.

Bloch, A., Y. Folman, M. Kaim, Z. Roth, R. Braw-Tal, and D. Wolfenson. 2006. Endocrine alterations associated with extended time interval between estrus and ovulation in high-yield dairy cows. J. Dairy Sci. 89:4694-4702. https://doi.org/10.3168/jds.S0022 $-0302(06) 72520-6$.

Cardozo, L. L., A. Thaler Neto, G. N. Souza, L. C. A. Picinin, N. C. Felipus, N. L. M. Reche, F. A. Schmidt, D. Werncke, and E. E. Simon. 2015. Risk factors for the occurrence of new and chronic cases of subclinical mastitis in dairy herds in southern Brazil. J. Dairy Sci. 98:7675-7685. https://doi.org/10.3168/jds.2014-8913.

Department of Animal Production and Health. 2015a. Livestock population distribution by districts. Pages 6-7 in Livestock Statistical Bulletin 2015, Department of Animal Production and Health, Peradeniya, Sri Lanka. Accessed May 14, 2021. http://www.daph.gov .lk/web/images/content_image/publications/other_publications/ stat_bulletin_2015.PDF.

Department of Animal Production and Health. 2015b. Status of livestock diseases in third quarter 2015. Pages 3-5 in Veterinary Epidemiological Bulletin 8. Department of Animal Production and Health, Peradeniya, Sri Lanka. Accessed May 14, 2021. http:// www.daph.gov.lk/web/images/content_image/news_bulletins/ epidemiological/2015_july_sep.pdf.

Department of Census and Statistics. 2020. Number of livestock farmers 2015. Accessed March 21, 2021. http://www.statistics.gov.lk/ Agriculture/StaticalInformation/rubb7.

Erskine, R. J. 2001. Mastitis control in dairy herds. Pages 397-435 in Herd Health: Food Animal Production. 3rd ed. O. M. Radostits, ed. W. B. Saunders Company.

Fuenzalida, M. J., P. M. Fricke, and P. L. Ruegg. 2015. The association between occurrence and severity of subclinical and clinical mastitis on pregnancies per artificial insemination at first service of Holstein cows. J. Dairy Sci. 98:3791-3805. https://doi.org/10 .3168/jds.2014-8997.

Furman, O., G. Leitner, Z. Roth, Y. Lavon, S. Jacoby, and D. Wolfenson. 2014. Experimental model of toxin-induced subclinical mastitis and its effect on disruption of follicular function in cows. Theriogenology 82:1165-1172. https://doi.org/10.1016/j.theriogenology 2014.08.002.

Gilbert, R. O., W. T. K. Bosu, and A. T. Peter. 1990. The effect of Escherichia coli endotoxin on luteal function in Holstein heifers. Theriogenology 33:645-651. https://doi.org/10.1016/0093 -691x(90)90541-z.

Gómez-Cifuentes, C. I., A. I. Molineri, M. L. Signorini, D. Scandolo, and L. F. Calvinho. 2014. The association between mastitis and reproductive performance in seasonally-calved dairy cows managed on a pasture-based system. Arch. Med. Vet. 46:197-206. https:/ doi.org/10.4067/S0301-732X2014000200005.

Gunawardana, S., D. Thilakarathne, I. S. Abegunawardana, P. Abeynayake, C. Robertson, and C. Stephen. 2014. Risk factors for bovine mastitis in the Central Province of Sri Lanka. Trop. Anim. Health Prod. 46:1105-1112. https://doi.org/10.1007/s11250-014 -0602-9. 
Halasa, T., K. Huijps, O. Østeras, and H. Hogeveen. 2007. Economic effects of bovine mastitis and mastitis management: A review. Vet. Q. 29:18-31. https://doi.org/10.1080/01652176.2007.9695224.

Hansen, P. J., P. Soto, and R. P. Natzke. 2004. Mastitis and fertility in cattle: Possible involvement of inflammation or immune activation in embryonic mortality. Am. J. Reprod. Immunol. 51:294-301. https://doi.org/10.1111/j.1600-0897.2004.00160.x.

Hiitiö, H., J. Vakkamäki, H. Simojoki, T. Autio, J. Junnila, S. Pelkonen, and S. Pyörälä. 2017. Prevalence of subclinical mastitis in Finnish dairy cows: Changes during recent decades and impact of cow and herd factors. Acta Vet. Scand. 59:22. https://doi.org/ 10.1186/s13028-017-0288-x.

Hogeveen, H., K. Huijps, and T. J. G. M. Lam. 2011. Economic aspects of mastitis: New developments. N Z Vet. J. 59:16-23. https: //doi.org/10.1080/00480169.2011.547165.

Hudson, C. D., A. J. Bradley, J. E. Breen, and M. J. Green. 2012. Associations between udder health and reproductive performance in United Kingdom dairy cows. J. Dairy Sci. 95:3683-3697. https:// doi.org/10.3168/jds.2011-4629.

Islam, M. A., M. Z. Islam, M. A. Islam, M. S. Rahman, and M. T. Islam. 2011. Prevalence of sub-clinical mastitis in dairy cows in selected areas of Bangladesh. Bangladesh J. Vet. Med. 9:73-78. https://doi.org/10.3329/bjvm.v9i1.11216.

Katsande, S., G. Matope, M. Ndengu, and D. M. Pfukenyi. 2013. Prevalence of mastitis in dairy cows from smallholder farms in Zimbabwe. Onderstepoort J. Vet. Res. 80:523. https://doi.org/10 .4102 /ojvr.v80i1.523.

Kayesh, M. E. H., M. Talukder, and A. K. M. M. Anower. 2014. Prevalence of subclinical mastitis and its association with bacteria and risk factors in lactating cows of Barisal district in Bangladesh. Int. J. Biol. Res. 2:35-38. https://doi.org/10.14419/ijbr.v2i2.2835.

Klaas, I. C., U. Wessels, H. Rothfuss, B. A. Tenhagen, W. Heuwieser, and E. Schallenberger. 2004. Factors affecting reproductive performance in German Holstein-Friesian cows with a special focus on postpartum mastitis. Livest. Prod. Sci. 86:233-238. https://doi .org/10.1016/j.livprodsci.2003.09.004.

Lavon, Y., E. Ezra, G. Leitner, and D. Wolfenson. 2011a. Association of conception rate with pattern and level of somatic cell count elevation relative to time of insemination in dairy cows. J. Dairy Sci. 94:4538-4545. https://doi.org/10.3168/jds.2011-4293.

Lavon, Y., M. Kaim, G. Leitner, D. Biran, E. Ezra, and D. Wolfenson. 2016. Two approaches to improve fertility of subclinical mastitic dairy cows. J. Dairy Sci. 99:2268-2275. https://doi.org/10.3168/ jds.2015-9745.

Lavon, Y., G. Leitner, E. Klipper, U. Moallem, R. Meidan, and D. Wolfenson. 2011b. Subclinical, chronic intramammary infection lowers steroid concentrations and gene expression in bovine preovulatory follicles. Domest. Anim. Endocrinol. 40:98-109. https:// doi.org/10.1016/j.domaniend.2010.09.004.

Lavon, Y., G. Leitner, H. Voet, and D. Wolfenson. 2010. Naturally occurring mastitis effects on timing of ovulation, steroid and gonadotrophic hormone concentrations, and follicular and luteal growth in cows. J. Dairy Sci. 93:911-921. https://doi.org/10.3168/ jds.2009-2112.

Lidet, G. M., B. Deressa, F. Begna, and A. Mekuria. 2013. Study on prevalence of bovine mastitis in lactating cows and associated risk factors in and around Areka town, Southern of Ethiopia. Afr. J. Microbiol. Res. 7:5051-5056. https://doi.org/10.5897/AJMR2013 .6202 .

Loeffler, S. H., M. J. de Vries, and Y. H. Schukken. 1999. The effects of time of disease occurrence, milk yield, and body condition on fertility of dairy cows. J. Dairy Sci. 82:2589-2604. https://doi.org/ 10.3168/jds.S0022-0302(99)75514-1.

Losinger, W. C. 2005. Economic impacts of reduced milk production associated with an increase in bulk-tank somatic cell count on US dairies. J. Am. Vet. Med. Assoc. 226:1652-1658. https://doi.org/ 10.2460/javma.2005.226.1652.

Mann, G. E., and G. E. Lamming. 2001. Relationship between maternal endocrine environment, early embryo development and inhibition of the luteolytic mechanism in cows. Reproduction 121:175180. https://doi.org/10.1530/rep.0.1210175.
Mohapatra, A., and M. Ashutosh. 2017. Influence of mastitis type on reproductive performance of Karan Fries cows during early lactation. J. Anim. Res. 7:879-883. https://doi.org/10.5958/2277-940X .2017.00134.6.

Neijenhuis, F., H. W. Barkema, H. Hogeveen, and J. P. T. M. Noordhuizen. 2001. Relationship between teat-end callosity and occurrence of clinical mastitis. J. Dairy Sci. 84:2664-2672. https://doi .org/10.3168/jds.S0022-0302(01)74720-0.

Nguyen, T. C., T. Nakao, G. Gautam, L. T. Su, R. M. S. B. K. Ranasinghe, and M. Yusuf. 2011. Relationship between milk somatic cell count and post-partum ovarian activity and fertility in dairy cows. Acta Vet. Hung. 59:349-362. https://doi.org/10.1556/avet 2011.017.

Olivares-Pérez, J., A. E. Kholif, S. Rojas-Hernández, M. M. M. Y. Elghandour, A. Z. M. Salem, A. Z. Bastida, D. Velázquez-Reynoso, M. Cipriano-Salazar, L. M. Camacho-Díaz, M. U. Alonso-Fresán, and N. DiLorenzo. 2015. Prevalence of bovine subclinical mastitis, its etiology and diagnosis of antibiotic resistance of dairy farms in four municipalities of a tropical region of Mexico. Trop. Anim. Health Prod. 47:1497-1504. https://doi.org/10.1007/s11250-015 -0890-8.

Peake, K. A., A. M. Biggs, C. M. Argo, R. F. Smith, R. M. Christley, J. E. Routly, and H. Dobson. 2011. Effects of lameness, subclinical mastitis and loss of body condition on the reproductive performance of dairy cows. Vet. Rec. 168:301-306. https://doi.org/10 $.1136 /$ vr.c6180.

Pinedo, P. J., P. Melendez, J. A. Villagomez-Cortes, and C. A. Risco. 2009. Effect of high somatic cell counts on reproductive performance of Chilean dairy cattle. J. Dairy Sci. 92:1575-1580. https:/ /doi.org/10.3168/jds.2008-1783.

Quinn, P. J., M. E. Carter, B. Markey, and G. R. Carter. 1999. Mastitis. Pages 327-335 in Clinical Veterinary Microbiology. 1st ed. Elsevier Ltd.

Rahularaj, R., R. M. C. Deshapriya, and R. M. S. B. K. Ranasinghe. 2019. Influence of bovine sub-clinical mastitis and associated risk factors on calving interval in a population of crossbred lactating cows in Sri Lanka. Trop. Anim. Health Prod. 51:2413-2419. https: //doi.org/10.1007/s11250-019-01957-4.

Rainard, P., G. Foucras, J. R. Fitzgerald, J. L. Watts, G. Koop, and J. R. Middleton. 2018. Knowledge gaps and research priorities in Staphylococcus aureus mastitis control. Transbound. Emerg. Dis. 65(Suppl. 1):149-165. https://doi.org/10.1111/tbed.12698.

Rainard, P., and C. Riollet. 2006. Innate immunity of the bovine mammary gland. Vet. Res. 37:369-400. https://doi.org/10.1051/vetres: 2006007.

Ranasinghe, D. K. P. C., D. I. Abeygunawardana, and R. M. S. B. K. Ranasinghe. 2017. Evaluation of possible sources of raw milk contamination and hygienic practices of small scale dairy farmers in Makandura area. Page 116 in 5th Undergraduate Research Symposium, Faculty of Livestock, Fisheries and Nutrition. Wayamba University of Sri Lanka, Makandura, Gonawila (NWP).

Ravinath, W. T., R. M. S. B. K. Ranasinghe, S. N. T. De Silva, R. M. C. Deshapriya, and R. W. P. M. Rajapaksha. 2014. Development of a PCR based method to detect Staphylococcus aureus in Bovine subclinical mastitis. Pages 287-290 in International Symposium on Agriculture and Environment, 27 November 2014, Faculty of Agriculture, University of Ruhuna, Sri Lanka.

Samarakoon, S. J. M. R. R., A. Dangolla, and W. M. S. K. Karunarathne. 2014. Some findings of mastitis control programme in Badulla District in Sri Lanka in 2012. S. L. Vet. J. 61:11-13.

Sanotharan, N., M. Pagthinathan, and M. S. M. Nafees. 2016. Prevalence of bovine subclinical mastitis and its association with bacteria and risk factors in milking cows of Batticaloa district in Sri Lanka. Int. J. Sci. Res. Innov. Technol. 3:137-150.

Santman-Berends, I. M. G. A., J. M. Swinkels, T. J. G. M. Lam, J. Keurentjes, and G. van Schaik. 2016. Evaluation of udder health parameters and risk factors for clinical mastitis in Dutch dairy herds in the context of a restricted antimicrobial usage policy. J. Dairy Sci. 99:2930-2939. https://doi.org/10.3168/jds.2015-10398.

Santos, J. E. P., R. L. A. Cerri, M. A. Ballou, G. E. Higginbotham, and J. H. Kirk. 2004. Effect of timing of first clinical mastitis oc- 
currence on lactational and reproductive performance of Holstein dairy cows. Anim. Reprod. Sci. 80:31-45. https://doi.org/10.1016/ S0378-4320(03)00133-7.

Schams, D., and B. Berisha. 2004. Regulation of corpus luteum function in cattle: An overview. Reprod. Domest. Anim. 39:241-251. https://doi.org/10.1111/j.1439-0531.2004.00509.x.

Schrick, F. N., M. E. Hockett, A. M. Saxton, M. J. Lewis, H. H. Dowlen, and S. P. Oliver. 2001. Influence of subclinical mastitis during early lactation on reproductive parameters. J. Dairy Sci. 84:1407-1412. https://doi.org/10.3168/jds.S0022-0302(01)70172 -5 .

Seegers, H., C. Fourichon, and F. Beaudeau. 2003. Production effects related to mastitis and mastitis economics in dairy cattle herds. Vet. Res. 34:475-491. https://doi.org/10.1051/vetres:2003027.

Sharma, N. 2007. Alternative approach to control intramammary infection in dairy cows: A review. Asian J. Anim. Vet. Adv. 2:50-62. https://doi.org/10.3923/ajava.2007.50.62.

Sharma, N., S. G. Singh, Z. I. Huma, S. Sharma, J. Misri, S. K. Guptaand, and K. Hussain. 2018. Mastitis occurrence pattern in dairy cows and importance of related risk factors in the occurrence of mastitis. J. Anim. Res. 8:315-326. https://doi.org/10.30954/2277 $-940 X .04 .2018 .23$.

Siatka, K., A. Sawa, M. Bogucki, D. Piwczynski, and S. Krezel-Czopek. 2019. The relationships between the somatic cell counts in the milk and the fertility of Polish Holstein-Friesian cows. Vet. Med. (Praha) 64:433-439. https://doi.org/10.17221/34/2019-VETMED.

Sisay, G., M. Alo, B. Ketema, S. Teshale, T. Fanos, and J. Tariku. 2012. Study on prevalence of bovine mastitis and its major causative agents in West Harerghe zone, Doba district, Ethiopia. J. Vet. Med. Anim. Health 4:116-123. https://doi.org/10.5897/ JVMAH12.016.

Soto, P., R. Natzke, and P. Hansen. 2003. Identification of possible mediators of embryonic mortality caused by mastitis: Actions of lipopolysaccharide, prostaglandin F2 $\alpha$, and the nitric oxide generator, sodium nitroprusside dihydrate, on oocyte maturation and embryonic development in cattle. Am. J. Reprod. Immunol. 50:263-272. https://doi.org/10.1034/j.1600-0897.2003.00085.x.

Spencer, T. E., G. A. Johnson, R. C. Burghardt, and F. W. Bazer. 2004. Progesterone and placental hormone actions on the uterus: Insights from domestic animals. Biol. Reprod. 71:2-10. https://doi .org/10.1095/biolreprod.103.024133.

Suzuki, C., K. Yoshioka, S. Iwamura, and H. Hirose. 2001. Endotoxin induces delayed ovulation following endocrine aberration during the proestrous phase in Holstein heifers. Domest. Anim. Endocrinol. 20:267-278. https://doi.org/10.1016/S0739-7240(01)00098-4.

Sztachańska, M., W. Baranski, T. Janowski, J. Pogorzelska, and S. Zdunczyk. 2016. Prevalence and etiological agents of subclinical mastitis at the end of lactation in nine dairy herds in North-East Poland. Pol. J. Vet. Sci. 19:119-124. https://doi.org/10.1515/pjvs $-2016-0015$.

Taponen, S., E. Liski, A. M. Heikkilä, and S. Pyörälä. 2017. Factors associated with intramammary infection in dairy cows caused by coagulase-negative staphylococci, Staphylococcus aureus, Streptococcus uberis, Streptococcus dysgalactiae, Corynebacterium bovis, or Escherichia coli. J. Dairy Sci. 100:493-503. https://doi.org/10 .3168/jds.2016-11465.

Taponen, S., H. Simojoki, M. Haveri, H. D. Larsen, and S. Pyorala. 2006. Clinical characteristics and persistence of bovine mastitis caused by different species of coagulase-negative staphylococci identified with API or AFLP. Vet. Microbiol. 115:199-207. https:/ /doi.org/10.1016/j.vetmic.2006.02.001.

Tyler, J. W., J. S. Cullor, and D. C. Ruffin. 1993. Immunization and immunotherapy for mastitis. Vet. Clin. North Am. Food Anim. Pract. 9:537-549. https://doi.org/10.1016/S0749-0720(15)30620-4.

Viguier, C., S. Arora, N. Gilmartin, K. Welbeck, and R. O'Kennedy. 2009. Mastitis detection: Current trends and future perspectives. Trends Biotechnol. 27:486-493. https://doi.org/10.1016/j.tibtech .2009.05.004.

Villa-Arcila, N. A., J. Sanchez, M. H. Ratto, J. C. Rodriguez-Lecompte, P. C. Duque-Madrid, S. Sanchez-Arias, and A. Ceballos-Marquez. 2017. The association between subclinical mastitis around calving and reproductive performance in dairy cows. Anim. Reprod. Sci. 185:109-117. https://doi.org/10.1016/j.anireprosci.2017.08.010.

Wang, L., F. Yang, X. J. Wei, Y. J. Luo, W. Z. Guo, X. Z. Zhou, and Z. T. Guo. 2019. Prevalence and risk factors of subclinical mastitis in lactating cows in Northwest China. Isr. J. Vet. Med. 74:17-22.

Wickramasuriya, U. G. J. S. 1985. Evaluation of a mastitis control programme adopted in small dairies in the district of Colombo. J. Natl. Sci. Found. Sri Lanka 13:17-28. https://doi.org/10.4038/ jnsfsr.v13i1.8346.

Yamane, I., M. Eguchi, T. Tsutsui, and K. Shimura. 2003. Investigation of risk factors associated with the incidence of bovine mastitis. Pages 1-3 in 11th International Symposium of the World Association of Veterinary Laboratory Diagnosticians and OIE Seminar on Biotechnology; Bangkok, Thailand. Thai Veterinary Medical Association.

Zelinski-Wooten, M. B., J. S. Hutchison, I. Trinchard-Lugan, D. L. Hess, D. P. Wolf, and R. L. Stouffer. 1997. Initiation of periovulatory events in gonadotrophin-stimulated macaques with varying doses of recombinant human chorionic gonadotrophin. Hum. Reprod. 12:1877-1885. https://doi.org/10.1093/humrep/12.9.1877. 